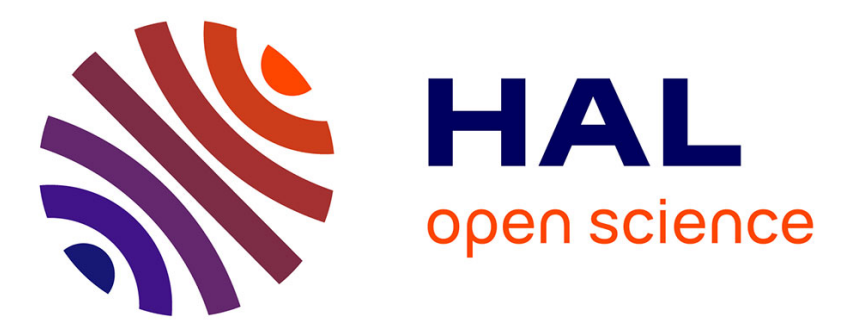

\title{
Updated Global and Oceanic Mercury Budgets for the United Nations Global Mercury Assessment 2018
}

P. Outridge, R. Mason, F. Wang, S. Guerrero, Lars-Eric Heimbürger-Boavida

\section{To cite this version:}

P. Outridge, R. Mason, F. Wang, S. Guerrero, Lars-Eric Heimbürger-Boavida. Updated Global and Oceanic Mercury Budgets for the United Nations Global Mercury Assessment 2018. Environmental Science and Technology, 2018, 52 (20), pp.11466-11477. 10.1021/acs.est.8b01246 . hal-01921166

\section{HAL Id: hal-01921166 https://hal.science/hal-01921166}

Submitted on 19 Feb 2019

HAL is a multi-disciplinary open access archive for the deposit and dissemination of scientific research documents, whether they are published or not. The documents may come from teaching and research institutions in France or abroad, or from public or private research centers.
L'archive ouverte pluridisciplinaire HAL, est destinée au dépôt et à la diffusion de documents scientifiques de niveau recherche, publiés ou non, émanant des établissements d'enseignement et de recherche français ou étrangers, des laboratoires publics ou privés. 


\title{
Critical Review
}

Subscriber access provided by UNIVERSITY OF CONNECTICUT

\section{Updated global and oceanic mercury budgets for the United Nations Global Mercury Assessment 2018}

\author{
Peter M. Outridge, Robert P. Mason, Feiyue Wang, Saul Guerrero, and Lars-Eric Heimburger
}

Environ. Sci. Technol., Just Accepted Manuscript • DOI: 10.1021/acs.est.8b01246 • Publication Date (Web): 18 Sep 2018

Downloaded from http://pubs.acs.org on September 20, 2018

\section{Just Accepted}

"Just Accepted" manuscripts have been peer-reviewed and accepted for publication. They are posted online prior to technical editing, formatting for publication and author proofing. The American Chemical Society provides "Just Accepted" as a service to the research community to expedite the dissemination of scientific material as soon as possible after acceptance. "Just Accepted" manuscripts appear in full in PDF format accompanied by an HTML abstract. "Just Accepted" manuscripts have been fully peer reviewed, but should not be considered the official version of record. They are citable by the Digital Object Identifier (DOI®). "Just Accepted" is an optional service offered to authors. Therefore, the "Just Accepted" Web site may not include all articles that will be published in the journal. After a manuscript is technically edited and formatted, it will be removed from the "Just Accepted" Web site and published as an ASAP article. Note that technical editing may introduce minor changes to the manuscript text and/or graphics which could affect content, and all legal disclaimers and ethical guidelines that apply to the journal pertain. ACS cannot be held responsible for errors or consequences arising from the use of information contained in these "Just Accepted" manuscripts. 
1 Updated global and oceanic mercury budgets for the United Nations Global Mercury Assessment 2018

2

3

4

by

5

6

P.M. Outridge ${ }^{1,2 *}$, R.P. Mason ${ }^{3}$, F. Wang ${ }^{2}$, S. Guerrero ${ }^{4}$ and L.E. Heimbürger-Boavida ${ }^{5}$

7

8

1: Geological Survey of Canada, Natural Resources Canada, 601 Booth St., Ottawa, ON K1A 0E8, Canada

9 2: Center for Earth Observation Science, Department of Environment and Geography, University of Manitoba, Winnipeg, MB R3T 2N2, Canada

3: Department of Marine Sciences, University of Connecticut, 1080 Shennecossett Road, Groton, CT 06340, USA

4: Universidad Metropolitana, Autopista Caracas Guarenas, Caracas 1073, Venezuela.

14

5: Aix Marseille Université, CNRS/INSU, Université de Toulon, IRD, Mediterranean Institute of Oceanography (MIO) UM 110, 13288, Marseille, France.

16

17

18

19

$20 *$ Corresponding author email address: peter.outridge@canada.ca (P.M. Outridge) 


\section{Abstract}

22 In support of international efforts to reduce mercury $(\mathrm{Hg})$ exposure in humans and wildlife, this paper

23 reviews the literature concerning global $\mathrm{Hg}$ emissions, cycling and fate, and presents revised global and

24 oceanic Hg budgets for the 2018 United Nations Global Mercury Assessment. We assessed two

25 competing scenarios about the impacts of $16^{\text {th }}$ - late $19^{\text {th }}$ century New World silver $(\mathrm{Ag}) \mathrm{mining}$, which

26 may be the largest human source of atmospheric $\mathrm{Hg}$ in history. Consideration of $\mathrm{Ag}$ ore geochemistry,

27 historical documents on Ag production, and comparison of the scenarios against atmospheric $\mathrm{Hg}$

28 patterns in environmental archives, strongly support a "low mining emission" scenario. Building upon

29 this scenario and other published work, the revised global budget estimates human activities including

30 recycled legacy emissions have increased current atmospheric $\mathrm{Hg}$ concentrations by about $450 \%$ above

31 natural levels (prevailing before $1450 \mathrm{AD}$ ). Current anthropogenic emissions to air are $2.5 \pm 0.5 \mathrm{kt} / \mathrm{y}$. The

32 increase in atmospheric $\mathrm{Hg}$ concentrations has driven a $~ 300 \%$ average increase in deposition, and a

$33230 \%$ increase in surface marine waters. Deeper marine waters show increases of only $12-25 \%$. The

34 overall increase in $\mathrm{Hg}$ in surface organic soils $(\sim 15 \%)$ is small due to the large mass of natural $\mathrm{Hg}$ already

35 present from rock weathering, but this figure varies regionally. Specific research recommendations are

36 made to reduce uncertainties, particularly through improved understanding of fundamental processes

37 of the $\mathrm{Hg}$ cycle, and continued improvements in emissions inventories from large natural and

38 anthropogenic sources. 
Mercury $(\mathrm{Hg})$ is released into the environment as a result of human activities, as well as by natural

41 sources and processes such as volcanoes and rock weathering. ${ }^{1,2}$ Following its release, $\mathrm{Hg}$ is transported

42 and recycled among the major environmental compartments - air, soils and waters - until it is

43 eventually removed from the surface system through burial in coastal and deep ocean sediments, lake

44 sediments, and subsurface soils. ${ }^{2,3}$ However, owing to its long residence times in the oceans and soils, current concentrations of $\mathrm{Hg}$ in the environment are well above those that can be explained by current releases. Therefore, consideration of historical emissions from natural and anthropogenic sources, and

47 the on-going recycling of this 'legacy' $\mathrm{Hg}$, is an important part of understanding the current global $\mathrm{Hg}$ budget. ${ }^{4-7} \mathrm{~A}$ small fraction on average of the $\mathrm{Hg}$ in global aquatic environments is present as monomethylmercury - the only $\mathrm{Hg}$ form that biomagnifies in food chains - although it can be a larger

50 fraction in some ocean regions and specific water masses. ${ }^{2}$ For the sake of simplicity, monomethylmercury is referred to by its generic name, methylmercury (MeHg). Many of the processes

52 involved in $\mathrm{Hg}$ methylation, or influencing MeHg uptake into food chains, are still inadequately

53 understood ${ }^{8,9}$, which contributes to the difficulties in precisely predicting the effects of regulatory

54 action on wildlife and human $\mathrm{Hg}$ exposure.

To address the global problem of Hg pollution, the Minamata Convention was adopted by the United Nations in 2013 (www.mercuryconvention.org) and entered into force in August 2017. As part of efforts

57 to support the Convention, the United Nations Environment Programme (UNEP) is undertaking regular assessments of the scientific literature on $\mathrm{Hg}$ at five-year intervals. An improved quantitative understanding of the global $\mathrm{Hg}$ cycle is important for our capacity to predict how regulatory actions to reduce emissions will affect $\mathrm{Hg}$ concentrations in different environmental compartments, biota and

61 humans. Given its scale and biogeochemical complexity, and the lack of detailed information for many 62 of its aspects, the planetary $\mathrm{Hg}$ cycle is best described using budgets derived from global-scale models 
63 and literature compilations. This review presents a synthesis of recent advances since the AMAP/UNEP

64 report $^{1}$ in our understanding of the global $\mathrm{Hg}$ cycle, including an evaluation of the influence of historical emissions on current anthropogenic $\mathrm{Hg}$ levels in the biosphere, and provides updated global and oceanic total $\mathrm{Hg}$ budgets that are incorporated into the 2018 Global Mercury Assessment. ${ }^{10}$

\section{A General Overview of Recent Advances}

68 In the technical background report to the 2013 Global Mercury Assessment ${ }^{1}$, based on a global budget developed by Mason et al. ${ }^{11}$, it was estimated that human activities had increased atmospheric $\mathrm{Hg}$ concentrations by $300-500 \%$ since about the end of the $19^{\text {th }}$ century. Mercury concentrations in surface ocean waters less than 200 m deep had increased on average by 200\% over the past century, whereas deeper waters exhibited smaller increases (11-25\%) because of the century- to millennium-scale residence times of these slowly overturning water masses. The average $\mathrm{Hg}$ increase in surface organic

74 soils was estimated at $\sim 20 \%$ and was negligible in mineral soils.

75 Recent studies ${ }^{4,7,12,13}$ have emphasized the point that the end of the $19^{\text {th }}$ century, or even the last few centuries of the so-called "pre-industrial period", are not a suitable natural or "pre-anthropogenic"

77 reference point from which to gauge the full impact of human activities on the current global Hg cycle.

78 Studies of Hg consumption and production during New World precious metal and cinnabar (Hg ore)

79 mining from the $16^{\text {th }}$ century onwards ${ }^{14,15}$, and re-examination of the atmospheric Hg fluxes recorded in

80 long lake sediment and peat cores covering most of the last millennium ${ }^{7}$, indicate that significant

81 amounts of $\mathrm{Hg}$ were emitted by human activities in the period after the $16^{\text {th }}$ century, and before the

82 mid-19 ${ }^{\text {th }}$ century when the "pre-industrial period" is often regarded as having ended (e.g., $\left.{ }^{16,17}\right)$. There $^{10}$

83 are different definitions of a time that represents truly natural or 'pre-anthropogenic' conditions: e.g.,

$842000 \mathrm{BC}^{13}, 3000 \mathrm{BC}$ to $1550 \mathrm{AD}^{7}$, or prior to $1450 \mathrm{AD} .^{18}$ For the purposes of this review we adopted 85 Zhang et al.'s ${ }^{5}$ definition of 1450 AD as the end of the pre-anthropogenic era. 
As with almost all global trace metal budgets, uncertainties exist regarding the amounts of

87 anthropogenic and natural $\mathrm{Hg}$ 'stored' in different environmental compartments, the fluxes between them, and the rates of removal of $\mathrm{Hg}$ from the biosphere. ${ }^{1}$ Major ongoing efforts have been mounted to reduce these uncertainties. Since 2011, additional measurements of $\mathrm{Hg}$ concentrations and fluxes in oceans, atmosphere and soils have led to suggested refinements of global budgets and models ${ }^{4-7,12,13,}$ ${ }^{18-20}$. Major uncertainties persist, however, especially in estimates of the amount of anthropogenic Hg in

92 the oceans (cf. ${ }^{5,13}$ ). comprehensive, recent global $\mathrm{Hg}$ budgets generally agree that human activities have increased atmospheric $\mathrm{Hg}$ concentrations by a similar range: $450 \%{ }^{5}$ to $660 \%{ }^{13}$, such that total atmospheric concentrations today are 5.5-fold to 7.6-fold higher than natural levels, respectively. These estimates

97 include revolatilized legacy $\mathrm{Hg}$. There are greater differences in the budgets' estimates of atmospheric $98 \mathrm{Hg}$ deposition increases. Zhang et al. ${ }^{5}$ calculated that there had been an average 4.8 -fold increase in deposition to oceans and a 7.8-fold increase to land. However, Amos et al. ${ }^{13}$, by modeling various emission scenarios and comparing these trends with a re-evaluation of long peat and lake sediment cores, and the Hg concentration in surface reservoirs, proposed substantially higher increases. Median 102 increases in $\mathrm{Hg}$ accumulation rates between the pre-anthropogenic period and the 20th century peak were a factor of $\sim 26$ in peat bogs and $\sim 14$ in lake sediments, with both archive types showing increases 104 of about 5-fold between the pre-anthropogenic and the pre-industrial (i.e., 1760-1880) periods. By analysing $\mathrm{Hg}$ isotopes in Pyrenean peat cores, Enrico et al. ${ }^{21}$ reported that maximum $20^{\text {th }}$ century concentrations of gaseous elemental $\mathrm{Hg}(\mathrm{Hg}(0)$; GEM) were $15 \pm 4$ times higher than in the early- to mid-

107 Holocene. These increases are several times higher than other, sediment-based literature had indicated, of a 3-fold increase due to anthropogenic activities. ${ }^{2,16,22}$ Amos et al. ${ }^{7}$ attributed the lower estimates to an erroneous selection of natural deposition values that were too high, because they were based on $18^{\text {th }}$ 
110 and early $19^{\text {th }}$ century sediment samples that were already contaminated with mining-emitted $\mathrm{Hg}$. Thus,

111 studies since about 2012 indicate that the true impact of anthropogenic emissions on atmospheric $\mathrm{Hg}$

112 deposition, based on a comparison to pre-anthropogenic values, is greater than previous comparisons to

113 the $19^{\text {th }}$ century had suggested. But there is considerable variation in the estimates of the degree of that 114 impact.

115 The differences between the two most recent global budgets ${ }^{5,13}$ are most apparent in their estimates of 116 the amount of anthropogenic Hg in today's oceans. The primary cause is their varying estimates of the 117 amount and environmental fate of atmospheric emissions from historical silver $(\mathrm{Ag})$, cinnabar $(\mathrm{Hg})$ and 118 gold $(\mathrm{Au})$ mining in the Americas between the $16^{\text {th }}$ and late $19^{\text {th }}$ centuries, and to differences in the 119 estimated amount of natural $\mathrm{Hg}$ originally present in the oceans. Both studies based their global budget 120 calculations on Streets et al.'s ${ }^{4}$ all-time emission inventory, with Zhang et al. ${ }^{5}$ reducing the emissions 121 from Ag mining by three-fold. For convenience, we will refer to these two emissions scenarios as "low 122 mining emissions" and "high mining emissions", represented by Zhang et al. ${ }^{5}$ and Amos et al., ${ }^{13}$

123 respectively, although each of these papers is underpinned by a wealth of supporting literature 124 published before and since their respective publication. Overall, the chemical rate constants used for 125 modelling circulation processes within and between oceanic, atmospheric and terrestrial compartments 126 are a secondary factor differentiating the two scenarios.

127 Considerable $\mathrm{Hg}$ releases to land, freshwaters and air are known to have occurred from the mining and 128 production of $\mathrm{Ag}$ (as well as $\mathrm{Hg}$ and $\mathrm{Au}$ ) in South/Central America during the Spanish colonial period 129 (about 1520-1850 AD), and later from North American artisanal and small-scale mining during the "Gold 130 Rush" era (roughly 1850-1920). ${ }^{15,23-25}$ It is generally agreed that some fraction of the $\mathrm{Hg}$ from both 131 historical periods is still circulating within the global biosphere, and that this has had an effect on 132 present-day environmental $\mathrm{Hg}$ levels. But quantification of that effect is uncertain. Thus, before revising 
133 the global and oceanic budgets, evidence for the impact of historic mining on the global environment

134 and its relative importance in the different scenarios must be evaluated.

\section{Influence of Historic Ag Mining on Anthropogenic Hg Emission Inventories}

136 The total amount of $\mathrm{Hg}$ currently in the environment reflects a mixture of sources: historical

137 anthropogenic releases to air, land and waters; historical natural inputs; and present-day anthropogenic

138 and natural releases. Streets et al.'s ${ }^{12}$ updated inventory of all-time Hg emissions concluded that

139 historic Ag mining and production was the largest single source of anthropogenic $\mathrm{Hg}$ to the

140 environment, contributing several-times more $\mathrm{Hg}$ to the atmosphere ( $146 \mathrm{kt}, 31 \%$ of total emissions)

141 than combined industrial and artisanal Au production (55.4 kt) or coal combustion (26.4 kt). Mercury

142 production, much of which was destined for use with small-scale Ag and Au mining, contributed the

143 second highest amount, $91.7 \mathrm{kt}$. Most of the Ag mining-related Hg releases to air occurred before 1920.

144 A historical analysis of elemental $\mathrm{Hg}$ importation and consumption in the $16^{\text {th }}$ to $19^{\text {th }}$ centuries, in what

145 is today Mexico, Peru and Bolivia, indicated that large quantities of liquid $\mathrm{Hg}$ were indeed used during

146 Spanish colonial Ag production. ${ }^{14}$ Mercury was also refined from cinnabar at two major sites in the

147 Spanish New World, as well as in California, and at Idrija and Almaden in Europe. ${ }^{15}$ During the 250 years

148 after 1560, records indicate that over $120 \mathrm{kt}$ of liquid $\mathrm{Hg}$ (average of at least $0.48 \mathrm{kt} / \mathrm{y}$ ) was imported

149 from Europe into the New World or produced in the region, and virtually all of this was lost to the

150 regional environment. ${ }^{26}$ Given the likely large scale of contraband $\mathrm{Hg}$ involved in mining, this amount

151 may be considerably underestimated. Because of the importance of legacy $\mathrm{Hg}$ in the modern

152 environment, a correct interpretation of the impact of historic Ag mining emissions on the current

153 global $\mathrm{Hg}$ budget is particularly critical. ${ }^{5,7,27}$

154 Streets et al.'s ${ }^{4,12}$ inventories assumed emission factors of $52 \%$ and $40 \%$, respectively, to calculate 155 atmospheric $\mathrm{Hg}$ emissions from historic Ag mining, based on Ag metal production data. These factors 
represent the putative fraction of the $\mathrm{Hg}$ utilized in $\mathrm{Hg}$ mining that was ultimately emitted to the

157 atmosphere, and were adapted from Nriagu's estimates ${ }^{23,24}$ based on artisanal Au mining. This form of

158 small-scale Au mining commonly used direct amalgamation of Au with elemental Hg (a physical

159 process), which was then heated to recover the Au. In contrast, the nature of Ag ore geochemistry, and

160 different Ag production practices, meant atmospheric $\mathrm{Hg}$ emissions were much lower per unit of historic

161 Ag metal production than from artisanal $\mathrm{Au} .^{14,15,27}$ Unlike $\mathrm{Au}$, the $\mathrm{Ag}$ in economic ores mostly does not

162 occur in its elemental form. Smelting (without any Hg involvement) was applied to Ag-rich galena (PbS)

163 or copper ores, producing about half of all global Ag production up to $1900 .^{27,28}$ Thus, Hg emissions from

164 this industry must have come only from the non-smelted half, using other ore types. Many other Ag-

165 rich ore bodies, including those in the New World, are predominantly silver sulfide (acanthite, $\left.\mathrm{Ag}_{2} \mathrm{~S}\right)$ with

166 silver chloride in varying proportions. ${ }^{15,29}$ Historic refining of these ores used Hg, and involved two

167 distinct but concurrent chemical reactions: an oxidative chloride leach to convert silver sulfide to silver

168 chloride, and a redox reaction with $\mathrm{Hg}$ to produce metallic silver from silver chloride, followed by

169 amalgamation of the $\mathrm{Ag}$ with excess $\mathrm{Hg}^{30}$ The $\mathrm{AgHg}$ amalgam was then heated to remove the $\mathrm{Hg}$. These

170 Spanish colonial practices were later employed during the $19^{\text {th }}$ century North American Gold Rush,

171 except that iron was added to the chemical slurry to reduce $\mathrm{Hg}$ loss to insoluble calomel $\left(\mathrm{Hg}_{2} \mathrm{Cl}_{2}\right){ }^{27} \mathrm{In}^{2}$

172 the refining process, the major cause of $\mathrm{Hg}$ loss was calomel formation, with minimal volatile emissions

173 even during the heating stage. ${ }^{27,30}$ Mercury was carefully controlled during these reactions and during

174 heating, and was recycled as much as possible because $\mathrm{Hg}$ was expensive relative to $\mathrm{Ag}$, unlike the

175 current situation where $\mathrm{Hg}$ is cheap relative to Au. The calomel reaction in the $\mathrm{Hg}$ treatment of $\mathrm{Ag}$ ores

176 has been confirmed by laboratory experiments. ${ }^{31}$ The waste rock tailings were typically disposed of with

177 the calomel, thereby burying it in soils and sediments, although its long-term fate in the environment

178 has not yet been studied. 
179 In contrast to the use of emission factors with Ag production data to estimate $\mathrm{Hg}$ releases, Guerrero ${ }^{14}$ 180 used importation statistics and consumption records on $\mathrm{Hg}$ itself, from Spanish colonial government and 181 independant observers. His calculations suggested that no more than 7-34\% of the $\mathrm{Hg}$ used during $\mathrm{Ag}$ 182 production was physically lost through volatilization, ground spills and in waste water, with 66-93\% of 183 the consumed $\mathrm{Hg}$ chemically transformed into calomel. Volatilization was thus a small fraction $(<34 \%)$ of 184 total $\mathrm{Hg}$ consumption. During the $19^{\text {th }}$ century, numerous sources reported $\mathrm{Hg}$ losses to air of less than $1 \%$ of the $\mathrm{Hg}$ consumed by refining ${ }^{15,27,30}$, owing to improvements in the equipment used to recapture and condense gaseous $\mathrm{Hg}$ after amalgamation and heating. Thus, the putative $40-52 \%$ emission factors

187 for Ag mining appear to be inconsistent with newly available historical and chemical information. Recognition of the importance of history and chemistry in resolving the role of Ag mining is an important recent advance, and represents a fundamental difference between the low and high mining emission scenarios discussed in this review.

191 The AMAP/UNEP report ${ }^{1}$ used an emission factor of $45 \%$ for $\mathrm{Hg}$ emissions from artisanal and small-scale 192 gold mining (ASGM) in the present-day. That estimate is not affected by the new evidence concerning 193 Ag mining. The Au amalgamation process with $\mathrm{Hg}$ does not involve calomel formation, and thus historic $194 \mathrm{Hg}$ losses from Ag mining are not representative of those from $\mathrm{ASGM}^{30}$, which are likely to be higher as there is little attempt to recover $\mathrm{Hg}$ during heating of the amalgam.

\section{$\underline{\text { Evidence from Natural Archives }}$}

197 Based on Guerrero ${ }^{14}$, Zhang et al. ${ }^{5}$ adopted a low emission factor of $17 \%$ for $\mathrm{Hg}$ from Spanish colonial 198 and $19^{\text {th }}$ century Gold Rush Ag mining. The resulting all-time cumulative anthropogenic emissions to air $199\left(190 \mathrm{kt}^{5}\right)$ were just over half those estimated by Streets et al. ${ }^{4}$ of $\left.351 \mathrm{kt}\right)$, with decidedly lower releases 200 during the Spanish colonial and Gold Rush periods (Fig. S1a). Modeling of Hg deposition based on the 201 low emission scenario predicted fluxes markedly closer to measured values in 120 widely dispersed lake 
202

203

204

205

206

207

208

209

210

211

212

213

214

215

216

217

218

219

220

221

222

223

224

225

sediments around the world, compared to those based on another model with the high emission scenario (see Fig. S1b, c, d). A more recent estimate for all-time anthropogenic releases to air at $472 \mathrm{kt}^{12}$ was even higher than Streets et al., ${ }^{4}$ because of added commercial product emissions after the late $19^{\text {th }}$ century ${ }^{6}$, but this addition would not affect the high emission scenario prediction concerning historical Ag mining.

Support for the low emission scenario came from an independent analysis by Engstrom et al. ${ }^{22}$ of another large global set of lake sediment $\mathrm{Hg}$ profiles independent from those in Zhang et al. ${ }^{5}$. Although atmospheric Hg deposition was substantially increased during the Spanish colonial period in one South American lake (Laguna Negrilla) near the major cinnabar mining and Hg production site of Huancavelica, Peru, there was little evidence of increased deposition at this time in sediment cores from many remote North American, Arctic or African lakes, suggesting that the contamination from $\mathrm{Ag}-, \mathrm{Hg}$ - and $\mathrm{Au}-\mathrm{mining}$ was, at most, limited to surrounding terrestrial, freshwater and coastal ecosystems in western South/Central America. ${ }^{22}$

Similarly, there is little evidence in natural archives to support a major atmospheric $\mathrm{Hg}$ impact from late $19^{\text {th }}$ century North American Gold Rush mining. Streets et al.'s ${ }^{4}$ results suggested a bimodal pattern of total anthropogenic $\mathrm{Hg}$ emissions to air and modeled atmospheric concentrations from 1850 onwards, with values in the 1890 s that were as high or higher than in the mid- to late $20^{\text {th }}$ century, due to a $450 \%$ increase in primary emissions mostly from Gold Rush Ag mining. A revision to include $\mathrm{Hg}$ releases from commercial products from the late 1800 s onwards $^{6}$ did not substantially diminish the late $19^{\text {th }}$ century peak in emissions and atmopheric concentrations $\left(\right.$ see $\left.^{12}\right)$. Although increases in $\mathrm{Hg}$ accumulation occurred in remote lake sediments at this time, they were small relative to those observed later in the $20^{\text {th }}$ century in the same core profiles. ${ }^{5,22,25}$ Thus, the world-wide lake sediment record appears to suggest a negligible global impact from $\mathrm{Ag}, \mathrm{Hg}$ and $\mathrm{Au}$ production during the $16^{\text {th }}$ to early $20^{\text {th }}$ centuries. Coincident increases in atmospheric emissions from other sources such as coal combustion and 
226 commercial Hg uses ${ }^{12,32}$ may have contributed to the steady increase of $\mathrm{Hg}$ in world-wide deposition

227 (see above) and in Arctic marine biota ${ }^{33}$ that started in the latter half of the $19^{\text {th }}$ century.

228 Amos et al. ${ }^{7}$ discounted the lake sediment evidence by arguing that sediments in general respond

229 relatively slowly and insensitively to changes in atmospheric $\mathrm{Hg}$ deposition compared with peat bogs.

230 Amos et al. ${ }^{7}$ also proposed that the Guerrero ${ }^{14}$ volatilization estimate was unrealistically low because it

231 omitted $\mathrm{Hg}$ losses during reprocessing of $\mathrm{Hg}$-containing $\mathrm{Ag}$ and Au products, and revolatilization from

232 solid mining wastes including calomel. There is some evidence that calomel may disproportionate to

$233 \mathrm{Hg}(0)$ and $\mathrm{Hg}(\mathrm{II})$ under ambient environmental temperatures and sunlight ${ }^{34}$, but the extent of such

234 disproportionation has not yet been studied under realistic controlled conditions. Evaluation of

235 alternative global model scenarios by Amos et al. ${ }^{7}$ suggested that the low emission scenario was

236 inconsistent with $\mathrm{Hg}$ measurements in present-day environmental matrices, as well as with the

237 magnitude of $\mathrm{Hg}$ enrichment in peat and some lake sediment archives. However, examination of the

238 published outputs in Amos et al. ${ }^{7}$ showed that the "mining reduced $3 x$ " scenario actually gave better

239 agreement with observed upper ocean total $\mathrm{Hg}$ concentrations and net oceanic evasion rates than the

240 high emission scenario based on Streets et al. ${ }^{4}$, with similar estimates for present-day soil $\mathrm{Hg}$

241 concentrations and net terrestrial flux (see Figs. 3d, 3g, 3f and 3h, respectively, in ref. 7). Furthermore,

242 the lake sediment-based interpretations (above) of Strode et al. ${ }^{25}$, Engstrom et al. ${ }^{22}$ and Zhang et al. ${ }^{5}$

243 were supported by peat bog studies from the Faroe Islands ${ }^{35}$, Maine, USA ${ }^{36}$, Swiss Jura Mountains ${ }^{37}$ and

244 the Pyrenees ${ }^{21}$ that all showed relatively muted $\mathrm{Hg}$ increases prior to 1900 , and with $20^{\text {th }}$ century

245 accumulation rates substantially higher than in the late $19^{\text {th }}$ century. Recently published high-resolution

246 marine sediment cores from a remote region in the Southern Ocean ${ }^{38}$, and off New England, USA ${ }^{39}$,

247 also provide no evidence of significant global dispersion of emissions from historic $\mathrm{Ag}, \mathrm{Hg}$ and $\mathrm{Au}$

248 mining. 
Additional independent evidence supporting the low emission scenario, and the sediment and peat bog

250

251

252

253

254

255

256

257

258

259

260

261

262

263

264

265

266

267

268

269

270

271

patterns, was provided by recent studies of glacier ice cores (Fig. 1). In contrast to the modeled $450 \%$

increase in global primary $\mathrm{Hg}$ emissions between 1850 and $1890^{12}$, three ice cores displayed increases in

Hg accumulation between $1840-60$ and $1880-1900$ of 40 to $150 \%$ (reanalysis of data from refs. ${ }^{40-42}$ ). All

three studies indicated that $\mathrm{Hg}$ accumulation rates were substantially greater after 1950 than in the late 1800s, in contrast to the high emission scenario prediction (see Fig. S1). Furthermore, in a core from Mount Logan, Yukon, the peak periods of Spanish colonial mining ( 1600-1850) and the North American Gold Rush (1850-1900) represented only $8 \%$ and 14\%, respectively, of total anthropogenic Hg deposition in the core, with $78 \%$ occurring during the $20^{\text {th }}$ century. ${ }^{40}$ Finally, it should be noted that the Freemont Glacier ice core, that has been cited as evidence to support significant emissions from the North American Gold Rush, has had its chronology revised. With this new dating, the Hg profile is now in good agreement with the other ice core studies, and shows little evidence for $\mathrm{Hg}$ emissions during the Gold Rush. ${ }^{43}$

Thus, the weight of natural archive evidence, as well as new historical and chemical information (above), supports the low mining emission scenario, and suggests that any atmospheric $\mathrm{Hg}$ emissions produced by historical $\mathrm{Ag}$, $\mathrm{Au}$ and $\mathrm{Hg}$ production were restricted to areas around some mining operations. Other studies have shown marked local contamination by nearby historic Ag, cinnabar and Au mining ${ }^{17,44}$, although these effects are not seen everywhere (e.g. ${ }^{43}$ ).

\section{Revised Global and Oceanic Total Hg Budgets}

Here we present the updated budgets included in the 2018 AMAP/UNEP report ${ }^{10}$, explain how they were developed, and specify how the two main contrasting views of the world's historical emissions ${ }^{5,7,13}$ compare with each other in terms of the current budget. In general, the revised global Hg budget (Fig. 2) was constructed by updating the previous version ${ }^{1,11}$ with results from Zhang et al.'s model ${ }^{5}$ and after 
272 consideration of much of the new information and mass and flux estimates published by different 273 groups since 2012 (see Table S1, Supplementary Material).

274 Estimates of the amounts of natural and anthropogenic $\mathrm{Hg}$ in the atmosphere by Amos et al. ${ }^{13}$ and 275 Zhang et al. ${ }^{5}$ agreed to within about $30 \%$ of the estimates in the AMAP/UNEP budget ${ }^{1}$ (Table 1 ). We 276 accepted Zhang et al.' $\mathrm{s}^{5}$ estimate that human activities have increased current atmospheric $\mathrm{Hg}$ 277 concentrations by about $450 \%$ above natural levels (defined as those prevailing before 1450 AD). This 278 represents an increase of $3.6 \mathrm{kt}$ in atmospheric $\mathrm{Hg}$ mass above the natural value of $0.8 \mathrm{kt}$, for a total of $2794.4 \mathrm{kt}$. We calculated that the increase in atmospheric $\mathrm{Hg}$ concentrations has driven a 300\% average 280 increase in deposition, which is the largest source of $\mathrm{Hg}(\sim 90 \%)$ entering the surface ocean. ${ }^{11}$ Surface marine waters have shown an average $230 \%$ increase in $\mathrm{Hg}$ concentrations above natural levels,

282 showing some lag with atmospheric changes given the longer residence time of $\mathrm{Hg}$ in surface waters.

283 Deeper marine waters in our budget show increases of only $12-25 \%$ owing to the slow rate of 284 penetration of anthropogenic $\mathrm{Hg}$ into the large deep-water reservoir, which is again consistent with the 285 literature ${ }^{18-20}$, and estimates of deep ocean Hg sediment accumulation. However, our estimate for 286 ocean accumulation (see Fig. 3), while consistent with prior literature and modeling, is lower than and 287 not consistent with Zaferani et al.'s ${ }^{38}$ recent Holocene-long marine sediment core study from remote 288 Antarctica, in a region of high sediment accumulation. More research is clearly needed to further 289 constrain the magnitude of deep ocean net burial. The overall increase in $\mathrm{Hg}$ in surface organic soils $290(\sim 15 \%)$ is small due to the large mass of natural Hg already present from rock weathering, but this 291 figure varies regionally because of variations in natural features and processes such as vegetation cover 292 and soil organic matter, as well as anthropogenic inputs. ${ }^{45}$

293 The new terrestrial reservoir and flux estimates (see Table 1 and Fig. 2) were updated from Driscoll et 294 al. ${ }^{19}$ and Amos et al. ${ }^{7}$ Specific fluxes were also adopted from Pacyna et al. ${ }^{46}$ and Cohen et al. ${ }^{47}$, who 295 advocated for particular values from biomass burning, soil and vegetation emissions, and geogenic 
296

297

298

299

300

301

302

303

304

305

306

307

308

309

310

311

312

313

314

315

316

317

318

319

sources. The revised soil plus vegetation emissions are lower than the AMAP/UNEP ${ }^{1}$ value, but for most of the remaining fluxes, the changes are relatively small $(<30 \%)$ compared to the previous estimates. Both Amos et al. ${ }^{13}$ and Zhang et al. ${ }^{5}$ suggested that soils globally contain more anthropogenic $\mathrm{Hg}$ than was stated in AMAP/UNEP ${ }^{1}$, and these more recent values were considered in our reanalysis. The relative anthropogenic:natural balance in riverine fluxes in Figs. 2 and 3 was revised considering the estimates of Zhang et al. ${ }^{5}$, Liu et al. ${ }^{48}$, and Kocman et al. ${ }^{49}$

Fluxes between the atmosphere and terrestrial and oceanic reservoirs were modified in accordance with our best estimate for global atmospheric anthropogenic emissions ( $2.5 \mathrm{kt} / \mathrm{yr}$ ), which is $25 \%$ higher than in AMAP/UNEP, ${ }^{1}$ and using the relative anthropogenic:natural flux estimates from Zhang et al. ${ }^{5}$ The higher emissions value reflects the fact that the documented emission inventory presented in the 2018 Global Mercury Assessment (2.15 kt/yr for $2015^{10}$ ) acknowledges that emissions for several sectors cannot be reliably quantified and so are omitted. Provisionally, these sectors, which include agricultural waste burning and municipal and industrial waste disposal, can be expected to contribute tens to hundreds of additional tonnes of atmospheric $\mathrm{Hg}$. The $2.5 \mathrm{kt} / \mathrm{yr}$ value adopted here is therefore considered to be a conservative estimate for use in a contemporary global budget calculation. This estimate contains several acknowledged uncertainties (especially for emissions from ASGM, and waste combustion) and so a relatively wide uncertainty of $\pm 0.5 \mathrm{kt} / \mathrm{yr}$ is included. Similarly, there is a large range in estimates for ocean evasion, and the value adopted here represents the lower evasion estimates from recent high-resolution measurements (e.g., ${ }^{50}$ ). A new estimate for total anthropogenic releases from point sources to freshwaters, of $0.6 \mathrm{kt} / \mathrm{yr}^{10}$, is included based on recent literature. ${ }^{7,49}$ An estimate for oil and gas releases to marine systems $\left(0.015 \mathrm{kt} / \mathrm{yr}^{10}\right)$ was insignificant compared with the other fluxes and so is not included in Fig. 2. No reliable estimates of natural terrestrial Hg fluxes to freshwaters at a global scale were available, and thus this pathway was not quantified. Riverine fluxes into the open ocean are reduced by particule scavenging and sedimentation in estuaries and coastal seas, and the estimate used 
320 here is the lowest of those in recent models $(3,5,7)$. Kocman et al.'s ${ }^{49}$ compilation and evaluation of 321 global freshwater $\mathrm{Hg}$ contamination suggested that Liu et al.'s ${ }^{48}$ measurements of Chinese riverine $\mathrm{Hg}$ 322 fluxes were consistent with their data, and were more reliable and significantly lower than Amos et al.'s 323 (2014) modeling study. Kocman et al. ${ }^{49}$ advocated for a relatively low global riverine flux value similar to 324 that of Sunderland and Mason ${ }^{51}$. The anthropogenic fraction in the freshwater flux entering oceans is 325 increased by upstream urban/industrial point sources so that the anthropogenic:natural ratio is higher 326 than the small anthropogenic fraction in organic soils ( 15\%) would suggest. Overall, flux uncertainties 327 in the budget should each be regarded as spanning a range of at least $\pm 20 \%$, and subject to future 328 revision. The mass budget is balanced to within $5 \%$.

329 A recent paper by Schuster et al. ${ }^{52}$ suggested that melting of permafrost in the Arctic could be a globally 330 significant additional source of soil $\mathrm{Hg}$ to the atmosphere and aquatic systems in future. A major reason 331 for discrepancies between that paper and other estimates of the soil $\mathrm{Hg}$ reservoir is the depth of $\mathrm{Hg}$ 332 concentration data integration. Mason et al. ${ }^{53}$ and most subsequent modeling and budget estimates 333 reported the amount of $\mathrm{Hg}$ in a surface active soil layer of a certain thickness $($ e.g. $10 \mathrm{~cm}$ ) or reflected a 334 specific soil pool (e.g., the fast recycling pool in many models; $\sim 4 \%$ of the total soil reservoir). Schuster 335 et al. ${ }^{52}$ intergrated to a depth of several meters, but then compared their values to the previous 336 estimates for surface pools. Such comparisons can lead to incorrect conclusions, and so for the soil 337 reservoir the integration depth is a critical parameter. Here we use the amount of $\mathrm{Hg}$ in the actively 338 recycling soil pool (i.e., with an average depth of $10 \mathrm{~cm}$ ).

339 With respect to the world's oceans, there are significant differences between recent papers concerning 340 the quantity of anthropogenic $\mathrm{Hg}$ presently circulating in seawater. ${ }^{5,7,13,20} \mathrm{Up}$ to 2012 , published 341 estimates of the oceanic anthropogenic $\mathrm{Hg}$ mass ranged over more than an order of magnitude, from 3427.2 to $263 \mathrm{kt}^{4}{ }^{4,11,51,53-57}$ Since then, Amos et al. ${ }^{13}$ derived another estimate ( $222 \mathrm{kt}$ ) near the upper end 343 of this range based on the historical mining-influenced high emission scenario. As described above, 
344 additional evidence published since 2012, and considerations of Ag ore geochemistry and production

345 techniques, strongly support Zhang et al.'s ${ }^{5}$ suggestion that the high emissions scenario is too high.

346 Even with the lower mining emissions scenario, Zhang et al.'s ${ }^{5}$ calculations indicated that the

347 cumulative impact of those emissions over four centuries has been substantial, with $67 \%$ of the increase

348 in oceanic $\mathrm{Hg}$ mass above natural levels occurring prior to 1920 , and mostly ascribed to $\mathrm{Ag}$ mining-

349 related airborne contamination. The total anthropogenic mass in today's oceans (66 kt) estimated by

350 Zhang et al. ${ }^{5}$ is in good agreement with another recent estimate $\left(58 \pm 16 \mathrm{kt}^{20}\right)$ derived using a different

351 methodology based on seawater $\mathrm{Hg}$ concentration profiles combined with anthropogenic $\mathrm{CO}_{2}$ and

352 remineralized phosphate as proxies for oceanic Hg distribution. That the two studies, using different

353 approaches, arrived at similar estimates increases confidence in the robustness of their conclusions.

354 Both recent estimates fall within the lower half of the previous range of values and are close to the

355 Mason et al. ${ }^{11}$ estimate of $53 \mathrm{kt}$ used in AMAP/UNEP ${ }^{1}$ (see Table 1).

356 Based on this revised global budget, the Hg budget in the world's oceans, as represented in Zhang et al. ${ }^{5}$

357 was updated in light of the mass balance fluxes and reservoirs in Fig. 2, and is presented in greater detail

358 in Fig. 3. The ratios of natural to anthropogenic $\mathrm{Hg}$ reported by Zhang et al. ${ }^{5}$ were retained for most of

359 the reservoirs and fluxes, although their relative increase in oceanic $\mathrm{Hg}$ mass due to anthropogenic

360 inputs is higher than in other publications. This difference was taken into account in updating and

361 revising their budget for this paper. In Figure 3, each reservoir and flux term includes both the natural

362 and anthropogenic contribution. The graphic also shows the cycling of $\mathrm{Hg}$ in the ocean through

363 scavenging by particulate organic matter, which is a major mechanism for transport of $\mathrm{Hg}$ between

364 surface waters and deep ocean (e.g., see ${ }^{38}$ ). In this graphic, the intermediate and deep waters are

365 combined, whereas they are treated separately in the global budget in Fig. 2. 
In addition to differences in the amount of anthropogenic $\mathrm{Hg}$ in the world's oceans, the balance of

367 anthropogenic $\mathrm{Hg}$ distribution between global soils and oceans differs between budgets, with oceans 368 holding either about as much anthropogenic $\mathrm{Hg}$ mass as the actively recycling soils ${ }^{1,5}$ or substantially 369 less. ${ }^{13}$ The difference between outcomes may be partly due to our lack of understanding of some of the 370 basic processes governing $\mathrm{Hg}$ transport and fate in the terrestrial environment. For example, recent 371 studies on atmospheric $\mathrm{Hg}$ dynamics under a range of different plant communities - from tundra plants 372 to temperate forests - continue to demonstrate that the direct uptake of GEM through the stomata of 373 plant leaves is much more significant than previously thought. ${ }^{58-63}$ Globally, litterfall containing GEM and 374 throughfall, and not direct wet and dry deposition of oxidized Hg species, may represent the largest net 375 flux of atmospheric $\mathrm{Hg}$ to terrestrial ecosystems, with estimates in the range of $1-2 \mathrm{kt} / \mathrm{yr}^{59,60,64}$

376 The inconsistencies that remain in the evidence concerning the actual rates of historical mining

377 emissions that affected the global atmosphere, soils and oceans, also impact the evidence supporting 378 these revised estimates of oceanic and global Hg cycling. The three-fold reduction in Ag mining 379 emissions by Zhang et al. ${ }^{5}$ brought their modelled emission and deposition history closer to the world380 wide lake sediment pattern (compared with the Streets et al. ${ }^{4,12}$ emission inventories and atmospheric 381 concentration calculations). However, the distinct bulge in modeled deposition during the late $19^{\text {th }}$ and 382 early $20^{\text {th }}$ centuries is unlike the steadily increasing trend in lake sediment, peat and glacial ice $\mathrm{Hg}$ 383 deposition (see Figs. 1 and S1), as well as in Arctic marine biota ${ }^{33}$ during the same period. A further 384 reduction in the mass of volatilized $\mathrm{Hg}$ from historical $\mathrm{Ag}$ and $\mathrm{Hg}$ production, which would not be 385 inconsistent with the evidence discussed above, would bring the low emission scenario, and the natural 386 archival records, into even closer agreement. There is recent evidence that further reductions may be 387 justified. Guerrero's ${ }^{27}$ analysis of reports from all global Ag mining jurisdictions between 1590 and 1895 388 suggested a total global $\mathrm{Hg}$ release to air from Ag mining of just $6 \mathrm{kt}$. By comparison, Zhang et al. ${ }^{5}$ and 389 Streets et al. ${ }^{12}$ estimated this release at $48 \mathrm{kt}$ and $146 \mathrm{kt}$ (most before 1920), respectively. These new 
estimates urgently need further investigation as they have significant potential implications for our understanding of the anthropogenic component of the modern global Hg cycle and budget. If implemented in future models, the additional reductions would reduce the estimated amount of anthropogenic $\mathrm{Hg}$ in modern oceans and soils.

\section{The Rate of Clearance of Anthropogenic Hg from the World's Oceans}

395 The differences between the alternate emission scenarios are associated with significant differences in 396 the implied response times of the oceans to current emission reductions. All global ocean-atmosphere 397 models predict that $\mathrm{Hg}$ clearance rates from most ocean basins will be slow relative to the rate of 398 emission reductions in future, such that removal of anthropogenic $\mathrm{Hg}$ from the world's oceans will take 399 many decades to centuries depending on the specific ocean basin and depth interval of the water mass 400 in question, as well as the trajectory of emission controls..$^{5,7,11,20}$ But according to Selin $^{65}$ and Engstrom 401 et al. ${ }^{22}$, the high emission scenario predicts much slower and delayed reductions in environmental $\mathrm{Hg}$ 402 levels following emission curbs than the low emissions scenario, because of the higher cumulative 403 anthropogenic $\mathrm{Hg}$ totals in the environment, especially the oceans. Even at current global emission 404 levels, there is a general scientific consensus that seawater and marine food chain $\mathrm{Hg}$ levels are likely to 405 substantially increase over time, because of the slow clearance rate of $\mathrm{Hg}$ from the world's oceans 406 coupled with additional legacy anthropogenic $\mathrm{Hg}$ released from soil and abandoned urban/industrial

407 sources into rivers and revolatilized into the air. ${ }^{66}$

408 Until significant deficiencies in our current understanding of marine $\mathrm{Hg}$ cycling are resolved, especially 409 for net ocean sediment burial rates and transformation rates between $\mathrm{Hg}$ species that influence the 410 major sinks for seawater $\mathrm{Hg}$ (evasion to the atmosphere and burial in sediments), and greater 411 consistency is achieved in the interpretation of natural archives of atmospheric $\mathrm{Hg}$ deposition, the 412 prediction of the timeline and effects of global emission reductions will remain uncertain. It is clear, 
413 however, that irrespective of these scientific uncertainties, emissions reductions are required to reverse

414 the trend in oceanic anthropogenic $\mathrm{Hg}$ back towards natural levels, owing to the long response time of

415 the subsurface ocean to changes in inputs. ${ }^{22,65,66}$

\section{The Main Uncertainties in Global Hg Models and Budgets}

417 In this section, we summarize knowledge gaps and recommendations for further research stated in or

418 developed from recent papers. ${ }^{5,9,13,20,22,67-70}$ Recommendations were selected on the basis of their

419 relevance to global or oceanic models and budgets. Scientific uncertainties can be grouped under two

420 headings: natural inputs and processes, and anthropogenic emissions.

\section{$421 \quad$ Uncertainties in natural inputs and processes}

422 Net removal rates of anthropogenic $\mathrm{Hg}$ from the surface ocean are the result of competition between

423 three simultaneously occurring natural processes: the particulate flux from the surface to the deep

424 ocean (the 'biological pump', involving particle scavenging, remineralization and sedimentation); the

425 mixing of surface and deep-ocean waters; and the net reduction of inorganic $\mathrm{Hg}$ (II) and subsequent

426 evasion of $\mathrm{Hg}(0)$ back into the atmosphere ${ }^{11,51}$. Some of the evaded $\mathrm{Hg}(0)$ is rapidly photo-oxidized in

427 the lower troposphere and re-deposited to the ocean surface. Additional coupled ocean-atmosphere

428 measurement studies are needed to comprehensively measure the concentrations of various $\mathrm{Hg}$ species

429 spatially and temporally, and to better understand the transport and transformation rates of these co-

430 occurring processes. The need is particularly acute in the Southern Hemisphere open oceans, as well as

431 in regions where elevated anthropogenic $\mathrm{Hg}$ concentrations can be expected, such as the eastern

432 equatorial Atlantic, eastern equatorial and high latitude Pacific, and northern Indian Oceans.

433 Uncertainties in the robustness of measurements of atmospheric and seawater $\mathrm{Hg}$ concentrations are

434 exacerbated by relatively large inter-laboratory comparison errors, and so there is a particular need to

435 improve the overall reliability of atmospheric and seawater $\mathrm{Hg}$ concentration and speciation 
measurements. Few inter-comparison efforts have been mounted (see a review of atmospheric $\mathrm{Hg}$

437 determinations ${ }^{71}$ ). Past intercalibration exercises for seawater have only addressed total $\mathrm{Hg}$, and the

438 results have indicated significant discrepancies among the participating laboratories. ${ }^{72}$ Future exercises

439 should continue the effort of attaining reliable data, and should be extended to include all $\mathrm{Hg}$ species,

440 even unstable species such as dimethyl $\mathrm{Hg}$ and dissolved $\mathrm{Hg}(0)$. The development of suitable seawater

441 reference materials is encouraged.

442 The role of natural inputs in the global $\mathrm{Hg}$ budget is poorly constrained by measurements but potentially

443 of major importance. If the actual rate of emissions from natural sources such as volcanoes, geothermal

444 systems and marine hydrothermal vents is markedly higher or lower than currently thought, this would

445 affect assumptions about the absolute amounts of, and relative balance between, natural and

446 anthropogenic sources which are fundamental to our understanding of the global $\mathrm{Hg}$ cycle. Published

447 estimates of global volcanic $\mathrm{Hg}$ emissions to air range over four orders of magnitude $(0.1-1000 \mathrm{t} / \mathrm{yr})^{73-77}$,

448 with a recent summation of the literature estimating $76 \pm 30 \mathrm{t} / \mathrm{yr}$ from quiescent volcanic degassing, not

449 including effusions or eruptions. ${ }^{77}$ For oceans, the AMAP/UNEP report ${ }^{1}$ estimated $<0.6 \mathrm{kt} / \mathrm{yr}$ total $\mathrm{Hg}$

450 input from hydrothermal vents, which was based on few data and no systematic studies. Two recent

451 GEOTRACES cruises in the North Atlantic and equatorial Pacific Oceans ${ }^{78,79}$ found conflicting evidence of

452 an effect from vents on seawater $\mathrm{Hg}$ concentrations. Some shallow vents may release a substantial

453 fraction of their emisisons at the surface as gas bubbles containing GEM. ${ }^{80}$ More direct observations of

454 focused and diffuse-flow vent fluids, gases and hydrothermal plumes are needed to better constrain the

$455 \mathrm{Hg}$ flux, and its contribution to the global Hg cycle. ${ }^{81}$ Submarine groundwater discharges (SGDs) are also

456 likely to bring important amounts of $\mathrm{Hg}$ into the ocean, but there are as yet insufficient data to quantify

457 their inputs globally. ${ }^{82}$ Several recent papers indicate that SGD inputs of $\mathrm{Hg}$ may be locally as important

458 as atmospheric inputs, at least in some coastal environments. ${ }^{83-87}$ Additionally, the recent findings of

459 Zaferani et al. ${ }^{38}$ that sediment burial fluxes of $\mathrm{Hg}$ in a region of high opal accumulation in Antarctica are 
much higher than the average values used in our budget and in recent models points to the need to

461 obtain better information on net $\mathrm{Hg}$ burial rates in ocean sediments, both in the coastal and deep

462 oceans.

463 Given the importance of terrestrial soils as possibly the largest reservoir of natural and legacy

464 anthropogenic $\mathrm{Hg}$, global budget calculations will benefit from a better understanding of terrestrial $\mathrm{Hg}$

465 cycling. ${ }^{62}$ The lack of knowledge on the actual reservoir size that may be interacting with other parts of

466 the biosphere has been highlighted by Schuster et al. ${ }^{52}$, who suggested that Arctic permafrost soils are

467 an under-appreciated major repository of $\mathrm{Hg}$. Although permafrost $\mathrm{Hg}$ is mainly natural in origin, it could

468 become an important part of the global $\mathrm{Hg}$ cycle in future. There is little understanding of precisely how

469 much and how rapidly $\mathrm{Hg}$ releases from this source may grow with future climate warming, but they are

470 expected to increase. Export of the stored $\mathrm{Hg}$ and organic matter could lead to greater MeHg production

471 in northern aquatic ecosystems. ${ }^{88}$ Other research priorities in this area include more measurements of

472 the evasion rates of $\mathrm{Hg}$ from soils and the release rates of $\mathrm{Hg}$ to water following degradation of soil

473 organic matter, as well as improvements in defining the foliar uptake $\mathrm{Hg}(0)$ pathway in global models.

\section{$474 \quad$ Uncertainties in anthropogenic emissions}

475 The absolute amounts in historical emission inventories, and especially the role of $\mathrm{Ag}$ metal mining, have

476 been questioned in recent work comparing model outputs with past $\mathrm{Hg}$ deposition rates, as

477 reconstructed from natural archives of atmospheric deposition (see above). Some of the uncertainty lies

478 with the natural archives. For example, a recent paper has shown that the $\mathrm{Hg}$ accumulation rates in a

479 Tibetan Plateau glacier ice core were one to two orders of magnitude lower than in a nearby lake

480 sediment, yet both archives yielded remarkably similar trends. ${ }^{42}$ Similarly, the sediment, peat and ice

481 core literature reviewed above displays similar $\mathrm{Hg}$ deposition trends over time, but different absolute

482 fluxes, with ice cores exhibiting the lowest values of all possibly because of $\mathrm{Hg}$ photoreduction of

483 deposited $\mathrm{Hg}(\mathrm{II})$ to $\mathrm{Hg}(0)$ and its revolatilization from snow surfaces. ${ }^{89}$ Given the apparent importance 
484 of historical deposition to current world $\mathrm{Hg}$ budgets and to future emission reduction scenarios, a 485 concerted effort to understand the reasons for the different findings from peat, lake sediment and 486 glacial ice archives is called for that would build upon earlier work. ${ }^{7,54,90,91}$ Arriving at an agreed 487 historical emission amount from precious metal mining would eliminate much of the uncertainty 488 surrounding current anthropogenic $\mathrm{Hg}$ inventories in soils and the oceans.

490 The accuracy of the recent atmospheric emission inventories, including that of AMAP/UNEP ${ }^{1}$, has also 491 been questioned in the literature, in part due to the inconsistency between the recent trends in primary 492 industrial emissions, which are flat or rising, and the large ( 30-40\%) decreases in atmospheric GEM 493 concentrations and wet deposition at background Northern Hemisphere monitoring stations since $4941990 .{ }^{22,69}$ Zhang et al. ${ }^{69}$ found that primary industrial emissions and GEM trends were brought into 495 closer agreement by accounting for the decline in $\mathrm{Hg}$ release from commercial products over this period, 496 by reducing the assumed volatilization rate of $\mathrm{Hg}$ from present-day ASGM, and by accounting for the 497 shift in $\mathrm{Hg}(0) / \mathrm{Hg}(\mathrm{II})$ speciation of emissions from coal-fired utilities after implementation of gaseous 498 pollutant control measures. Because the emission inventories are the basis of global modelling efforts, 499 resolving this discrepancy should improve the accuracy of global budgets and future trend scenarios. ASGM emissions were the largest anthropogenic source of atmospheric $\mathrm{Hg}$ in recent years, according to

501 AMAP/UNEP ${ }^{1}$, but this finding has been disputed. ${ }^{22,69}$ Verifiable and higher quality emission data from

502 ASGM operations are therefore a priority need. Studies of the speciation and distribution of the $\mathrm{Hg}$ 503 released into air, land and waters from present-day ASGM operations are also called for.

505 The identified uncertainties and knowledge gaps described above should not be construed as 506 undermining the rationale for the Minamata Convention on Mercury. All model and budget studies are 507 in agreement that current levels of anthropogenic $\mathrm{Hg}$ emissions are likely to lead to increased 
508 environmental exposure of wildlife and humans (albeit of varying magnitude in different species and

509 settings), and that reducing these emissions is a necessity for reducing their negative environmental and

510 health impacts. The uncertainties and knowledge gaps mainly affect our capability to predict where,

511 when, and by how much, rather than if, the environment will respond to reduced emissions.

\section{Acknowledgements}

514 This paper was prepared as a contribution to the United Nations Environment Programme's 2018 Global

515 Mercury Assessment, and we thank all of our colleauges who participated in this process, particularly G.

516 Futsaeter and E. Toda (UNEP), S. Wilson (AMAP) and J. Munthe (IVL Swedish Enviromental Research

517 Institute). The work was financially supported by UNEP, and by support from the Geological Survey of

518 Canada (G. Cotteret and B. Vigneault) to PMO. PMO was hosted by the Dept. of Geoscience, Aarhus

519 University, during preparation of this paper. RPM's involvement was supported by NSF Chemical

520 Oceanography grant \# 1634048, and Wang's involvement by the Canada Research Chair program. S.

521 Duckworth prepared the figures and C. Symon was copy editor. We kindly thank the following for access

522 to their raw data: E. Beal, S. Kang, D. Streets, C. Zdanowicz, Y. Zhang, and J. Zheng.

\section{Supporting Information Available}

525 Figure S1 presents the two contrasting estimates of global anthropogenic $\mathrm{Hg}$ emissions to air, and 526 associated atmospheric deposition to lakes through history as discussed in this review. Table S1

527 contains supporting information relevant to the development of the global and ocean budgets. This 528 information is available free of charge via the Internet at http://pubs.acs.org. 
1. AMAP/UNEP Technical Background Report for the Global Mercury Assessment 2013; Arctic Monitoring and Assessment Programme, Oslo, Norway/UNEP Chemicals Branch, Geneva, Switzerland, 2013; p 263.

2. Fitzgerald, W. F.; Lamborg, C. H., Geochemistry of mercury in the environment. In Treatise on Geochemistry, 2nd Ed, Elsevier: 2014.

3. Amos, H. M.; Jacob, D. J.; Kocman, D.; Horowitz, H. M.; Zhang, Y.; Dutkiewicz, S.; Horvat, M.; Corbitt, E. S.; Krabbenhoft, D. P.; Sunderland, E. M., Global biogeochemical implications of mercury discharges from rivers and sediment burial. Environ. Sci. Technol. 2014, 48, 9514-9522.

4. $\quad$ Streets, D. G.; Devane, M. K.; Lu, Z.; Bond, T. C.; Sunderland, E. M.; Jacob, D. J., All-time releases of mercury to the atmosphere from human activities. Environ. Sci. Technol. 2011, 45, 10485-10491. 5. Zhang, Y.; Jaeglé, L.; Thompson, L.; Streets, D. G., Six centuries of changing oceanic mercury. Global Biogeochem. Cycles 2014, 28, 1251-1261.

$542 \quad 6 . \quad H o r o w i t z$, H. M.; Jacob, D. J.; Amos, H. M.; Streets, D. G.; Sunderland, E. M., Historical mercury 543 releases from commercial products: Global environmental implications. Environ. Sci. Technol. 2014, 48, 544 10242-10250.

$545 \quad 7 . \quad$ Amos, H. M.; Sonke, J. E.; Obrist, D.; Robins, N.; Hagan, N.; Horowitz, H. M.; Mason, R. P.; Witt, M.; 546 Hedgecock, I. M.; Corbitt, E. S.; Sunderland, E. M., Observational and modeling constraints on global anthropogenic enrichment of mercury. Environ. Sci. Technol. 2015, 49, 4036-4047.

$548 \quad 8 . \quad$ Paranjape, A. R.; Hall, B. D., Recent advances in the study of mercury methylation in aquatic systems. 549 Facets 2017, 2, 85-119.

5509 9. $\quad$ Sonke , J. E.; Heimbürger, L.-E.; Dommergue, A., Mercury biogeochemistry: Paradigm shifts, 551 outstanding issues and research needs. Comptes Rendus Geoscience 2013, 345, 213-224.

552 10. AMAP/UNEP Technical Background Assessment for the 2018 Global Mercury Assessment; United 553 Nations Environment Programme: Geneva, Switzerland, 2018; (in press). 11. Mason, R. P.; Choi, A. L.; Fitzgerald, W. F.; Hammerschmidt, C. R.; Lamborg, C. H.; Soerensen, A. L.; Sunderland, E. M., Mercury biogeochemical cycling in the ocean and policy implications. Environ. Res. 2012, 119, 101-117.

$557 \quad$ 12. $\quad$ Streets, D. G.; Horowitz, H. M.; Jacob, D. J.; Lu, Z.; Levin, L.; ter Schure, A. F. H.; Sunderland, E. M., 558 Total mercury released to the environment by human activities. Environ. Sci. Technol. 2017, 51, 5969-5977.

559 13. Amos, H. M.; Jacob, D. J.; Streets, D. G.; Sunderland, E. M., Legacy impacts of all-time anthropogenic emissions on the global mercury cycle. Global Biogeochem. Cycles 2013, 27, 410-421.

14. Guerrero, S., Chemistry as a tool for historical research: Identifying paths of historical mercury pollution in the Hispanic New World. Bull. Hist. Chem. 2012, 37, 61-70.

15. Guerrero, S., The history of silver refining in New Spain, 16C to 18C: back to the basics. Hist. Technol. 2016, 32, 2-32.

16. Fitzgerald, W. F.; Engstrom, D. R.; Mason, R. P.; Nater, E. A., The case for atmospheric mercury contamination in remote areas. Environ. Sci. Technol. 1998, 32, 1-7.

17. Correla, J. P.; Valero-Garces, B. L.; Wang, F.; Martínez-Cortizas, A.; Cuevas, C. A.; Saiz-Lopez, A., 700 years reconstruction of mercury and lead atmospheric deposition in the Pyrenees (NE Spain). Atmos. Environ. 2017, 155, 97-107.

18. Zhang, Y.; Jaeglé, L.; Thompson, L., Natural biogeochemical cycle of mercury in a global threedimensional ocean tracer model. Global Biogeochem. Cycles 2014, 28, 553-570.

19. Driscoll, C. T.; Mason, R. P.; Chan, H. M.; Jacob, D. J.; Pirrone, N., Mercury as a global pollutant: sources, pathways, and effects. Environ. Sci. Technol. 2013, 47, 4967-4983.

20. Lamborg, C. H.; Hammerschmidt, C. R.; Bowman, K. L.; Swarr, G. J.; Munson, K. M.; Ohnemus, D. C.; Lam, P. J.; Heimbürger, L.-E.; Rijkenberg, M. J. A.; Saito, M. A., A global ocean inventory of anthropogenic mercury based on water column measurements. Nature 2014, 512, 65-68. 
21. Enrico, M.; Le Roux, G.; Heimburger, L. E.; Van Beek, P.; Souhaut, M.; Chmeleff, J.; Sonke, J. E., Holocene atmospheric mercury levels reconstructed from peat bog mercury stable isotopes. Environ. Sci. Technol. 2017, 51, 5899-5906.

22. Engstrom, D. R.; Fitzgerald, W. F.; Cooke, C. A.; Lamborg, C. H.; Drevnick, P. E.; Swain, E. B.; Balogh, S. J.; Balcom, P. H., Atmospheric Hg emissions from preindustrial gold and silver extraction in the Americas: A reevaluation from lake-sediment archives. Environ. Sci. Technol. 2014, 48, 6533-6543.

23. Nriagu, J. O., Legacy of mercury pollution. Nature 1993, 363, 589.

24. Nriagu, J. O., Mercury pollution from the past mining of gold and silver in the Americas. Sci. Total Environ. 1994, 149, 167-181.

25. Strode, S.; Jaegle, L.; Selin, N. E., Impact of mercury emissions from historic gold and silver mining: Global modeling. Atmos. Environ. 2009, 43, 2012-2017. 26. TePaske, J. J.; Brown, K. W., A New World of Gold and Silver. Brill: Leiden, 2010.

27. Guerrero, S. The environmental history of silver production, and its impact on the United Nations Minimata Convention on mercury; Extended Abstract, Session on Global Production and Distribution of Silver, World Economic History Congress, Boston, USA, July 29 - August 3, 2018. Available at: http://wehc2018.org/wp-content/uploads/2018/04/WEHCguerreroMinamata-2.pdf: 2018.

28. Director of U.S. Mint Annual Report of the Director of the U.S. Mint for the Fiscal Year Ended June 1944, including Report on the Production of Precious Metals During the Calendar Year 1943; Treasury Dept. Doc. 3133, U.S. Govt. Printing Office: Washington, 1945; p 101.

29. Sillitoe, R., Supergene silver enrichment reassessed. In Supergene Environments, Processes and Products, Titley, S. R., Ed. Society of Economic Geologists, Spec. Pub. 14: 2009; pp 15-32.

30. Guerrero, S., Silver by Fire, Silver by Mercury: A Chemical History of Silver Refining in New Spain and Mexico, 16th to 19th Centuries. Brill: Leiden, the Netherlands, 2017.

31. Johnson, D. A.; Whittle, K., The chemistry of the Hispanic-American amalgamation process. J. Chem. Soc. Dalton Trans. 1999, 4239-4243.

32. Streets, D. G.; Lu, Z.; Levin, L.; ter Schure, A. F. H.; Sunderland, E. M., Historical releases of mercury to air, land, and water from coal combustion. Sci. Total Environ. 2018, 615, 131-140.

33. Dietz, R.; Outridge, P. M.; Hobson, K. A., Anthropogenic contributions to mercury levels in presentday Arctic animals - A review. Sci. Total Environ. 2009, 407, 6120-6131.

34. Copan, L.; Fowles, J.; Barreau, T.; McGee, N., Mercury toxicity and contamination of households from the use of skin creams adulterated with mercurous chloride (calomel). Int. J. Environ. Res. Publ. Health 2015, 12, 10943-10954.

35. Shotyk, W.; Goodsite, M. E.; Roos-Barraclough, F.; Givelet, N.; Le Roux, G.; Weiss, D.; Cheburkin, A. K.; Knudsen, K.; Heinmeier, J.; van Der Knaap, W. O.; Norton, S. A.; Lohse, C., Accumulation rates and predominant atmospheric sources of naturla and anthropogenic $\mathrm{Hg}$ and $\mathrm{Pb}$ on the Faroe Islands. Geochim. Cosmochim. Acta 2005, 69, 1-17.

36. Roos-Barraclough, F.; Givelet, N.; Cheburkin, A. K.; Shotyk, W.; Norton, S. A., Use of Br and Se in peat to reconstruct the natural and anthropogenic fluxes of atmospheric $\mathrm{Hg}$ : a 10, 000-year record from Caribou Bog, Maine. Environ. Sci. Technol. 2006, 40, 3188-3194.

37. Roos-Barraclough, F.; Shotyk, W., Millennial-scale records of atmospheric mercury deposition obtained from ombrotrophic and minerotrophic peatlands in the Swiss Jura Mountains. Environ. Sci. Technol. 2003, 37, 235-244.

38. Zaferani, S.; Pérez-Rodríguez, M.; Biester, H., Diatom ooze - a large marine mercury sink. Science 2018, 10.1126/science.aat2735.

39. Fitzgerald, W. F.; Engstrom, D. R.; Hammerschmidt, C. R.; Lamborg, C. H.; Balcom, P. H.; Lima-Braun, A. L.; Bothner, M. H.; Reddy, C. M., Global and local sources of mercury deposition in coastal New England reconstructed from a multiproxy, high-resolution, estuarine sediment record. Environ. Sci. Technol. 2018, 52, 624 7614-7620. 
40. Beal, S. A.; Osterberg, E. C.; Zdanowicz, C. M.; Fisher, D. A., Ice core perspective on mercury pollution during the past 600 years. Environ. Sci. Technol. 2015, 49, 7641-7647.

41. Zheng, J., Archives of total mercury reconstructed with ice and snow from Greenland and the Canadian High Arctic. Sci. Total Environ. 2015, 509-510, 133-144.

42. Kang, S.; Huang, J.; Wang, F.; Zhang, Q.; Zhang, Y.; Li, C.; Wang, L.; Chen, P.; Sharma, C.; Li, Q.; Sillanpää, M.; Hou, J.; Xu, B.; Guo, J., Atmospheric mercury depositional chronology reconstructed from lake sediment and ice cores in the Himalayas and Tibetan Plateau. Environ. Sci. Technol. 2016, 50, 2859-2869.

43. Chellman, N.; McConnell, J. R.; Arienzo, M.; Pederson, G. T.; Aarons, S. M.; Csank, A., Reassessment of the Upper Fremont Glacier ice-core chronologies by synchronizing of ice-core-water isotopes to a nearby tree-ring chronology. Environ. Sci. Technol. 2017, 51, 4230-4238.

44. Cooke, C. A.; Hintelmann, H.; Ague, J. J.; Burger, R.; Biester, H.; Sachs, J. P.; Engstrom, D. R., Use and legacy of mercury in the Andes. Environ. Sci. Technol. 2013, 47, 4181-4188.

45. Obrist, D.; Pearson, C.; Webster, J.; Kane, K.; Lin, C. J.; Aiken, G. R.; Alpers, C. N., A synthesis of terrestrial mercury in the western United States: Spatial distribution defined by land cover and plant productivity. Sci. Total Environ. 2016, 568, 522-535.

46. Pacyna, J. M.; Travnikov, O.; De Simone, F.; Hedgecock, I. M.; Sundseth, K.; Pacyna, E. G.; Steenhuisen, F.; Pirrone, N.; Munthe, J.; Kindbom, K., Current and future levels of mercury atmospheric pollution on a global scale. Atmos. Chem. Phys. 2016, 16, 12495-12511.

47. Cohen, M. D.; Draxler, R. R.; Artz, R. S.; Blanchard, P.; Gustin, M. S.; Han, Y.-J.; Holsen, T. M.; Jaffe, D. A.; Kelley, P.; Lei, H.; Loughner, C. P.; Luke, W. T.; Lyman, S. N.; Niemi, D.; Pacyna, J. M.; Pilote, M.; Poissant, L.; Ratte, D.; Ren, X.; Steenhuisen, F.; Steffen, A.; Tordon, R.; S.J., W., Modeling the global atmospheric transport and deposition of mercury to the Great Lakes. Elementa 2016, 4, 000118.

48. Liu, M.; Chen, L.; Wang, X.; Zhang, W.; Tong, Y.; Ou, L.; Xie, H.; Shen, H.; Ye, X.; Deng, C.; Wang, H., Mercury export from mainland $C h i n a$ to adjacent seas and its influence on the marine mercury balance. Environ. Sci. Technol. 2016, 50, 6224-6232.

49. Kocman, D.; Wilson, S. J.; Amos, H. A.; Telmer, K. H.; Steenhuisen, F.; Sunderland, E. M.; Mason, R. P.; Outridge, P.; Horvat, M., Toward an assessment of the global inventory of present-day mercury releases to freshwater environments. Int. J. Environ. Res. Public Health 2017, 14, doi:10.3390/ijerph14020138.

50. Mason, R. P.; Hammerschmidt, C. R.; Lamborg, C. H.; Bowman, K. L.; Swarr, G. J.; Shelley, R. U., The air-sea exchange of mercury in the low latitude Pacific and Atlantic Oceans. Deep-Sea Res. 2017, 122, 17-28. 51. Sunderland, E. M.; Mason, R. P., Human impacts on open ocean mercury concentrations. Global Biogeochem. Cycles 2007, 21, doi:10.1029/2006GB002876.

52. Schuster, P. F.; Schaefer, K. M.; Aiken, G. R.; Antweier, R. C.; Dewild, J. F.; Gryziec, J. D.; Gusmeroli, A.; Hugelius, G.; Jafarov, E.; Krabbenhoft, D. L.; Liu, L.; Herman-Mercer, N.; Mu, C.; Roth, D. A.; Schaefer, T.; Striegal, R. G.; Wickland, K. P.; Zhan, T., Permafrost stores a globally significant amount of mercury. Geophys. Res. Lett. 2018, 45, 10.1002/2017GL075571.

53. Mason, R. P.; Fitzgerald, W. F.; Morel, F. M. M., The biogeochemical cycling of elemental mercury: Anthropogenic influences. Geochim. Cosmochim. Acta 1994, 58, 3191-3198.

54. Lamborg, C. H.; Fitzgerald, W. F.; O'Donnell, J.; Torgerson, T., A non-steady-state compartmental model of global-scale mercury biogeochemistry with interhemispheric gradients. Geochim. Cosmochim. Acta 2002, 66, 1105-1118.

55. Selin, N. E.; Jacob, D. J.; Yantosca, R. M.; Strode, S.; Jaeglé, L.; Sunderland, E. M., Global 3-D landocean-atmosphere model for mercury: present day versus preindustrial cycles and anthropogenic enrichment factors for deposition. Global Biogeochem. Cycles 2008, 22, GB2011.

56. Soerensen, A. L.; Sunderland, E. M.; Holmes, C. D.; Jacob, D. J.; Yantosca, R. M.; Skov, H.; Christensen, J. H.; Strode, S. A.; Mason, R. P., An improved global model for air-sea exchange of mercury: High concentrations over the North Atlantic. Environ. Sci. Technol. 2010, 44, 8574-8580. 
57. Strode, S.; Jaegle, L.; Emerson, S., Vertical transport of anthropogenic mercury in the ocean. Global Biogeochem. Cycles 2010, 24, GB4014.

58. Enrico, M.; Le Roux, G.; Marusczak, N.; Heimburger, L. E.; Claustres, A.; Fu, X.; Sun, R.; Sonke, J. E., Atmospheric mercury transfer to peat bogs dominated by gaseous elemental mercury dry deposition. Environ. Sci. Technol. 2016, 50, 2405-2412.

59. Fu, X.; Zhu, W.; Zhang, H.; Sommar, J.; Yu, B.; Yang, X.; Wang, X.; Lin, C.-J.; Feng, X., Depletion of atmospheric gaseous elemental mercury by plant uptake at Mt. Changbai, Northeast China. Atmos. Chem. Phys. 2016, 16, 12861-12873.

60. Wang, X.; Bao, Z.; Lin, C. J.; Yuan, W.; Feng, X., Assessment of global mercury deposition through litterfall. Environ. Sci. Technol. 2016, 50, 8548-8557.

61. Obrist, D.; Agnan, Y.; Jiskra, M.; Olson, C. L.; Colegrove, D. P.; Hueber, J.; Moore, C. W.; Sonke, J. E.; Helmig, D., Tundra uptake of atmospheric elemental mercury drives Arctic mercury pollution. Nature 2017, 547, 201-204.

62. Obrist, D.; Kirk, J. L.; Zhang, L.; Sunderland, E. M.; Jiskra, M.; Selin, N. E., A review of global environmental mercury processes in response to human and natural perturbations: Changes of emissions, climate, and land use. Ambio 2018, 47, 116-140.

63. Risch, M. R.; De Wild, J. F.; Gay, D. A.; Zhang, L.; Boyer, E. W.; Krabbenhoft, D. P., Atmospheric mercury deposition to forests in the eastern USA. Environ. Pollut. 2017, 228, 8-18.

64. Jiskra, M.; Sonke, J. E.; Obrist, D.; Bieser, J.; Ebinghaus, R.; Myhre, C. L.; Pfaffhuber, K. A.; Wängberg, I.; Kyllönen, K.; Worthy, D.; Martin, L. G.; Labuschagne, C.; Mkololo, T.; Ramonet, M.; Magand, O.; Dommergue, A., A vegetation control on seasonal variations in global atmospheric mercury concentrations. Nature Geosci. 2018, 11, 244-250.

65. Selin, N. E., Global change and mercury cycling: Challenges for implementing a global mercury treaty. Environ. Toxicol. Chem. 2014, 33, 1202-1210.

66. Sunderland, E. M.; Selin, N. E., Future trends in environmental mercury concentrations: implications for prevention strategies. Environ. Health 2013, 12.

67. Lamborg, C. H.; Hammerschmidt, C. R.; Bowman, K. L., An examination of the role of particles in oceanic mercury cycling. Phil. Trans. Royal Soc. A 2016, 374, 2081.

68. Song, S.; Selin, N. E.; Soerensen, A. L.; Angot, H.; Artz, R.; Brooks, S.; Brunke, E.; Conley, G.; Dommergue, A.; Ebinghaus, R.; Holsen, T.; Kang, S.; Kelley, P.; Luke, W.; Magand, O.; Marumoto, K.; Pfaffhuber, K. A.; Ren, X.; Zhang, Q., Top-down constraints on atmospheric mercury emissions and implications for global biogeochemical cycling. Atmos. Chem. Phys. 2015, 15, 7103-7125.

69. Zhang, Y.; Jacob, D. J.; Horowitz, H. M.; Chen, L.; Amos, H. M.; Krabbenhoft, D. P.; Slemr, F.; St. Louis, V. L.; Sunderland, E. M., Observed decrease in atmospheric mercury explained by global decline in atmospheric emissions. Proc. Nat. Acad. Sci. 2016, 113, 201516312.

70. Kwon, S. Y.; Selin, N. E., Uncertainties in atmospheric mercury modeling for policy evaluation. Current Pollut. Rep. 2016, 2, 103-114.

71. Gustin, M. S.; Amos, H. M.; Huang, J.; Miller, M. B.; Heidecorn, K., Measuring and modeling mercury in the atmosphere: a critical review. Atmos. Chem. Phys. 2015, 15, 5697-5713.

72. Lamborg, C. H.; Hammerschmidt, C. R.; Gill, G. A.; Mason, R. P.; Gichuki, S., An intercomparison of procedures for the determination of total mercury in seawater and recommendations regarding mercury speciation during GEOTRACES cruises. Limnol. Oceanogr. Methods 2012, 10, 90-100.

73. Nriagu, J. O., A global assessment of natural sources of atmospheric trace metals. Nature 1989, 338, 47-49.

74. Nriagu, J.; Becker, C., Volcanic emissions of mercury to the atmosphere: global and regional inventories. Sci. Total Environ. 2003, 304, 3-12.

75. Ferrara, R.; Mazzolai, B.; Lanzillotta, E.; Nucaro, E.; Pirrone, N., Volcanoes as emission sources of atmospheric mercury in the Mediterranean basin. Sci. Total Environ. 2000, 259, 115-121. 
760

761

762

763

764

765

76. Pyle, D. M.; Mather, T. A., The importance of volcanic emissions for the global atmospheric mercury cycle. Atmos. Environ. 2003, 37, 5115-5124.

77. Bagnato, E.; Tamburello, G.; Avard, G.; Martinez-Cruz, M.; Enrico, M.; Fu, X.; Sprovieri, M.; Sonke, J. E., Mercury fluxes from volcanic and geothermal sources: an update. In The Role of Volatiles in the Genesis, Evolution and Eruption of Arc Magmas, Zellmer, G. F.; Edmonds, M.; Straub, S. M., Eds. Geological Society: London, 2015; Vol. Special Publications, 410, p doi: 10.1144/SP410.2.

78. Bowman, K. L.; Hammerschmidt, C. R.; Lamborg, C. H.; Swarr, G. J., Mercury in the North Atlantic Ocean: The U.S. GEOTRACES zonal and meridional sections. Deep Sea Res // 2015, 116, 251-261.

79. Bowman, K. L.; Hammerschmidt, C. R.; Lamborg, C. H.; Swarr, G. J.; Agather, A. M., Distribution of mercury species across a zonal section of the eastern tropical South Pacific Ocean (U.S. GEOTRACES GP16). Mar. Chem. 2016, 186, 156-166.

80. Astakhov, A. S.; Ivanov, M. V.; Li, B. Y., Hydrochemical and atmochemical mercury dispersion zones over hydrothermal vents of the submarine Piip Volcano in the Bering Sea. Oceanology 2011, 51, 826-835.

81. German, C. R.; Casciotti, K. A.; Dutay, J. C.; Heimbürger, L. E.; Jenkins, W. J.; Measures, C. I.; Mills, R. A.; Obata, H.; Schlitzer, R.; Tagliabue, A.; Turner, D. R.; Whitby, H., Hydrothermal impacts on trace element and isotope ocean biogeochemistry. Phil. Trans. Royal Soc. A 2016, 374, 2081.

82. Moore, W. S., The effect of submarine groundwater discharge on the ocean. Ann. Rev. Mar. Sci. 2010, 2, 59-88.

83. Bone, S. E.; Charette, M. A.; Lamborg, C. H.; Gonneea, M. E., Has submarine groundwater discharge been overlooked as a source of mercury to coastal waters? Environ. Sci. Technol. 2007, 41, 3090-3095.

84. Black, F. J.; Paytan, A.; Knee, K. L.; De Sieyes, N. R.; Ganguli, P. M.; Gary, E.; Flegal, A. R., Submarine groundwater discharge of total mercury and monomethylmercury to central California coastal waters. Environ. Sci. Technol. 2009, 43, 5652-5659.

85. Ganguli, P. M.; Conaway, C. H.; Swarzenski, P. W.; Izbicki, J. A.; Flegal, A. R., Mercury speciation and transport via submarine groundwater discharge at a southern California coastal lagoon system. Environ. Sci. Technol. 2012, 42, 1480-1488.

86. Lee, Y.-G.; Rahman, M. D. M.; Kim, G.; Han, S., Mass balance of total mercury and monomethylmercury in coastal embayments of a volcanic island: significance of submarine groundwater discharge. Environ. Sci. Technol. 2011, 45, 9891-9900.

87. Laurier, F. J. G.; Cossa, D.; Beucher, C.; Breviere, E., The impact of groundwater discharges on mercury partitioning, speciation and bioavailability to mussels in a coastal zone. Mar. Chem. 2007, 104, 143155.

88. Stern, G. A.; Macdonald, R. W.; Outridge, P. M.; Wilson, S.; Chetelat, J.; Cole, A.; Hintelmann, H.; Loseto, L. L.; Steffen, A.; Wang, F.; Zdanowicz, C., How does climate change influence arctic mercury? Sci. Total Environ. 2012, 414, 22-42.

89. Douglas, T. A.; Loseto, L. L.; Macdonald, R. W.; Outridge, P.; Dommergue, A.; Poulain, A.; Amyot, M.; Barkay, T.; Berg, T.; Chetelat, J.; Constant, P.; Evans, M.; Ferrari, C.; Gantner, N.; Johnson, M. S.; Kirk, J.; Kroer, N.; Larose, C.; Lean, D.; Nielsen, T. G.; Poissant, L.; Rognerud, S.; Skov, H.; Sorensen, S.; Wang, F.; Wilson, S.; Zdanowicz, C. M., The fate of mercury in Arctic terrestrial and aquatic ecosystems, a review. Environ. Chem. 2012, 9, 321-355.

90. Biester, H.; Bindler, R.; Martinez-Cortizas, A.; Engstrom, D. R., Modeling the past atmospheric deposition of mercury using natural archives. Environ. Sci. Technol. 2007, 41, 4851-4860.

91. Outridge, P. M.; Rausch, N.; Percival, J. B.; Shotyk, W.; McNeely, R., Comparison of mercury and zinc profiles in peat and lake sediment archives with historical changes in emissions from the Flin Flon metal smelter, Manitoba, Canada. Sci. Total Environ. 2011, 409, 548-563. 


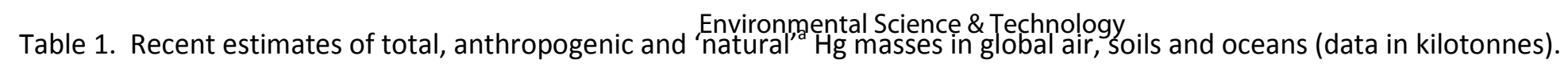

\begin{tabular}{|c|c|c|c|c|c|}
\hline & $\begin{array}{l}\text { Mason et al. }{ }^{11} \\
\text { AMAP/UNEP }\end{array}$ & Amos et al. ${ }^{13}$ & Zhang et al. ${ }^{5}$ & Lamborg et al. ${ }^{20}$ & Present study \\
\hline \multicolumn{6}{|l|}{ Atmospheric $\mathrm{Hg}$} \\
\hline Total & 5.1 & 5.3 & 4.4 & $\mathrm{n} / \mathrm{a}$ & 4.4 \\
\hline Anthropogenic & $3.4-4.1$ & 4.6 & 3.6 & $\mathrm{n} / \mathrm{a}$ & 3.6 \\
\hline Natural & $1.0-1.7$ & 0.7 & 0.8 & $\mathrm{n} / \mathrm{a}$ & 0.8 \\
\hline \multicolumn{6}{|c|}{ Soil Hg (organic layers) } \\
\hline Total & 201 & 271 & $\mathrm{n} / \mathrm{a}$ & $\mathrm{n} / \mathrm{a}$ & 150 \\
\hline Anthropogenic & 40 & 89 & 92 & $\mathrm{n} / \mathrm{a}$ & 20 \\
\hline Natural & 161 & 182 & $\mathrm{n} / \mathrm{a}$ & $\mathrm{n} / \mathrm{a}$ & 130 \\
\hline \multicolumn{6}{|l|}{ Oceanic $\mathrm{Hg}$} \\
\hline Total & 358 & 343 & 257 & 316 & 313 \\
\hline Anthropogenic & 53 & 222 & $66(38-106)^{c}$ & $58 \pm 16^{d}$ & 55 \\
\hline Natural & 305 & 122 & 191 & $258^{e}$ & 258 \\
\hline
\end{tabular}

767 a The time point for designation of the 'natural' Hg state, and thus the quantification of 'natural' and 'anthropogenic' Hg masses, differed

768 between studies: $2000 \mathrm{BC}$ in the 'pre-anthropogenic period, ${ }^{13}$; prior to $1450 \mathrm{AD}^{5,18}$ which preceded New World $\mathrm{Ag}$, Au and Hg production; and

769 about $1840 A D^{20}$ which was prior to the North American Gold Rush and the expansion of coal-fired combustion sources. The anthropogenic Hg

770 values from Mason et al. ${ }^{11}$ and Lamborg et al. ${ }^{20}$ are based on increases over the past 100 to 150 years, and thus their 'natural' Hg masses may

771 be over-estimated and the anthropogenic masses under-estimated compared with the other studies. ${ }^{b}$ estimates for this assessment modified

772 from Zhang et al. ${ }^{5}$ as described in text, and thus the anthropogenic values represent the impact of human activities since 1450 AD. ${ }^{c}$ uncertainty

773 range shown in brackets. ${ }^{d}$ based on an oceanic anthropogenic $\mathrm{Hg}$ :anthropogenic $\mathrm{CO}_{2}$ ratio for 1994; a more recent (higher) oceanic $\mathrm{CO}_{2}$

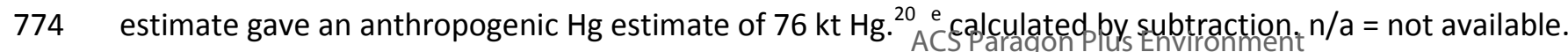




\section{Figure Captions}

Figure 1. Glacial ice core records of atmospheric Hg deposition from (a) Mount Logan, Yukon ${ }^{40}$, (b) Mount Geladaindong, Tibetan Plateau, China ${ }^{42}$, and (c) the NEEM site, Greenland ${ }^{41}$, compared with (d) the global atmospheric emission history since 1850 AD. ${ }^{12}$ Ice core Hg data are displayed: in (a) as mean \pm SD values; in (b) and (c) as 3-point running averages. In all ice core plots, the solid red lines indicate decadal median values calculated from raw data. In (d), atmospheric emissions from $\mathrm{Hg}$ (cinnabar) refining and Ag mining operations are shown separately from all other anthropogenic sources ("other").

Figure 2. Updated global Hg budget showing the anthropogenic impact on the $\mathrm{Hg}$ cycle since the pre-anthropogenic period (prior to $1450 \mathrm{AD}$ ). (See text for explanation of budget derivation. Ranges (where available) are given in brackets after the best estimate values; percentages in brackets represent the estimated increase in mass or flux due to human activities since the pre-anthropogenic period. Mass units in kilotonnes $(\mathrm{kt})$, fluxes in kilotonnes per year $(\mathrm{kt} / \mathrm{y}))$.

Figure 3. Natural and anthropogenic Hg fluxes and masses in the world's oceans. (Masses in kilotonnes (kt), and fluxes in (kt/y). Data adapted and revised from Zhang et al. ${ }^{5}$, based on the revised global budget shown in Fig. 2. Natural fluxes and masses in black, anthropogenic in red). 

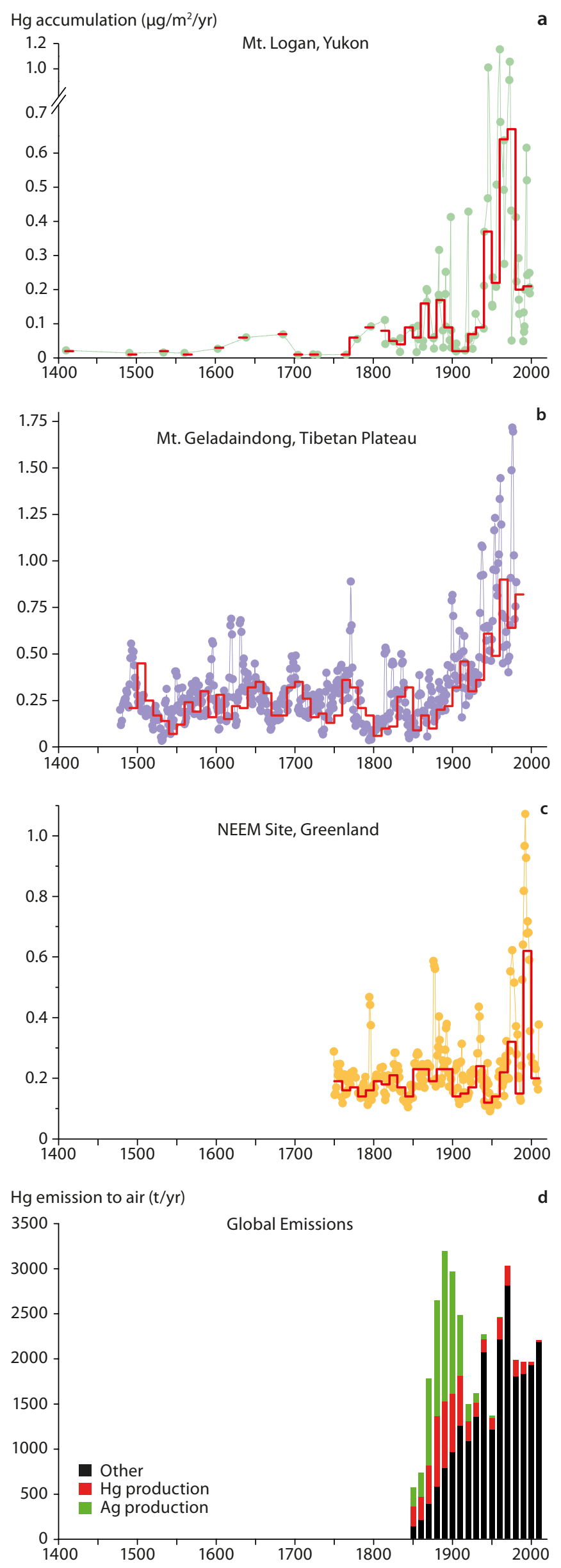
Atmosphere:

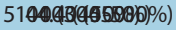

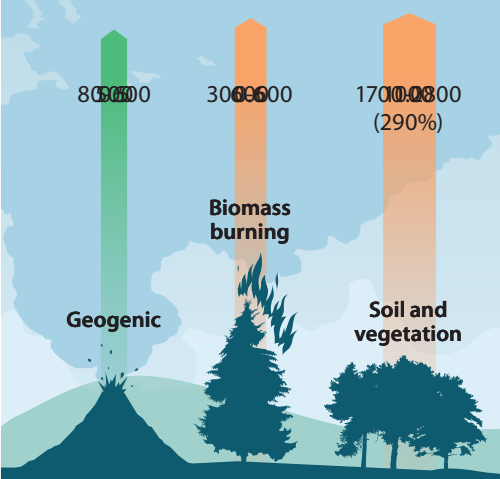

Organic soils: 20040i0/20\%\%)

Mineral soils: 800000 (n/s)

Anthropogenic

Natural

Re-emissions/Re-mobilisation
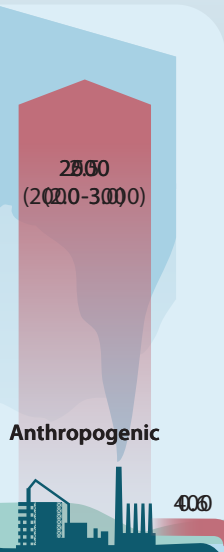

200
Net Hg0 evasion

2064050

(2 (2000)

(250\%)
DQppsisition

tøøoeanas

frfeeslowerater

3800

$3110 \%$

380

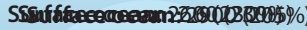

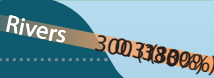

Intermediate waters:

13 Z1500(2(25\%)

Delepepatraters:

$22101000($ (1) 


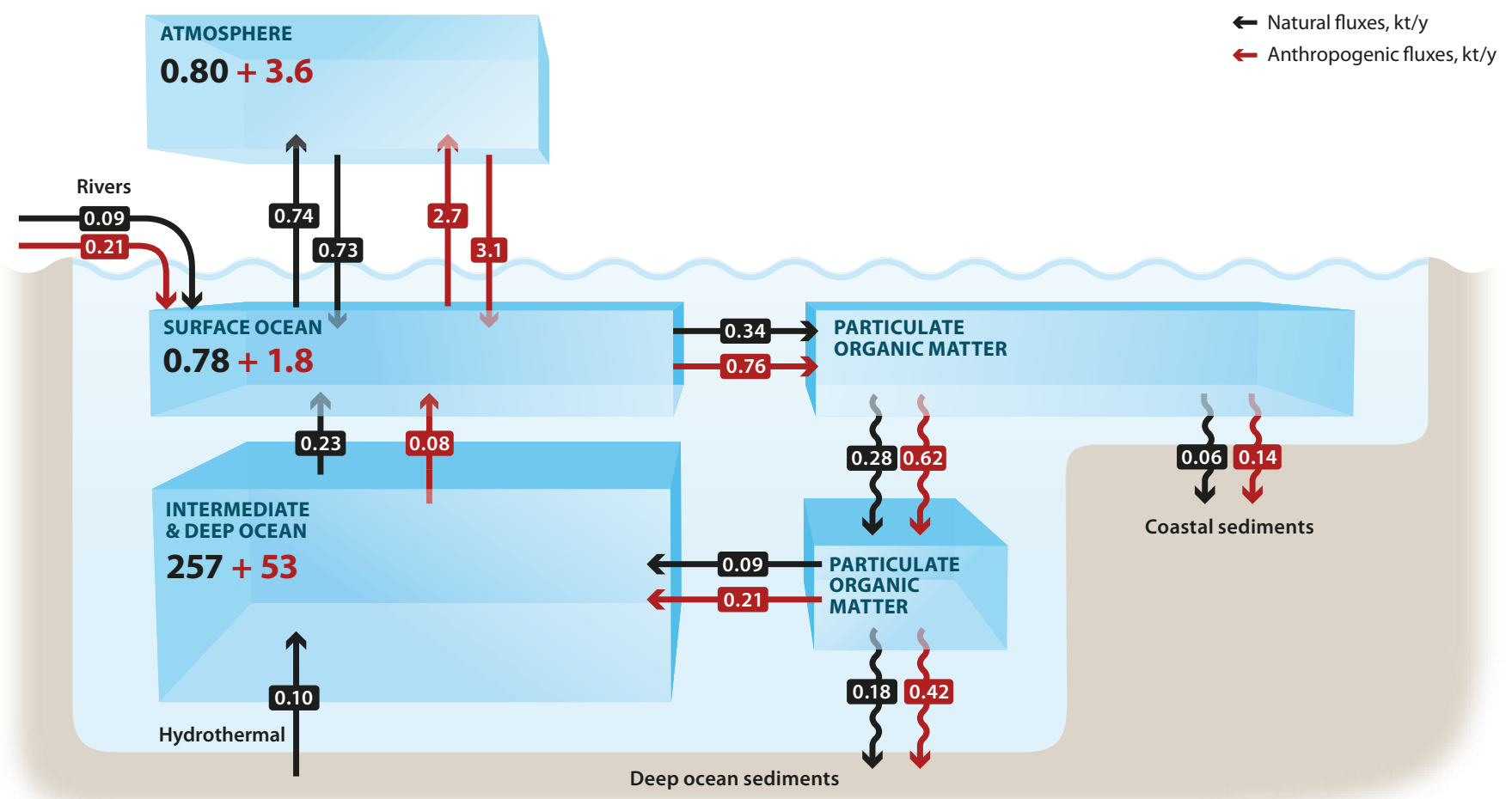




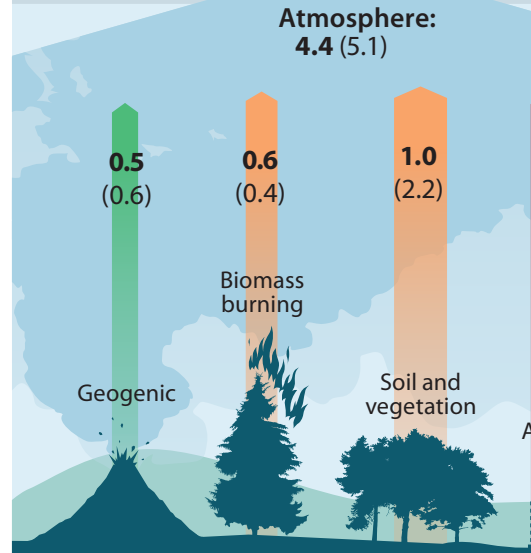

Organic soils: 150 (200)

Mineral soils: 800 (800)

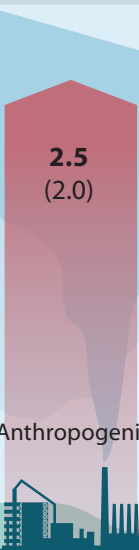

0.6
Deposition

to land/

freshwater
Deposition

to oceans

3.6

(3.2)
3.8

(3.7)
Net $\mathrm{Hg}^{0}$ evasion

3.4

(2.5)

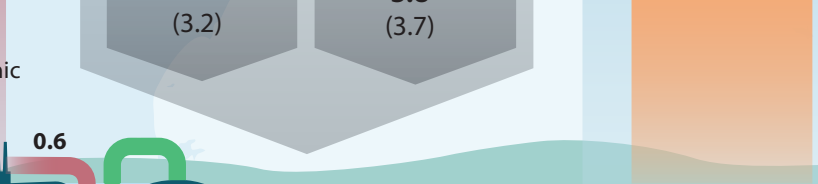

Surface ocean: $\mathbf{2 . 6}(2.9)$

Rivers

$0.3(0.4)$

Intermediate waters: 120 (134) Net vertical Gross export transport

Global Mercury Budget: AMAP/UNEP (2018) vs AMAP/UNEP (2013) Numbers in bold are from AMAP/UNEP (2018), those in brackets from AMAP/UNEP (2013)

Mass units are in kilotonnes (kt), fluxes in kilotonnes per year (kt/y)

Deep waters: $190(221)$

0.1 $(<0.6)$ 